\title{
A Comparative Study on the Analysis of Herbicide "Bromacil" Using ECD-gas Chromatography and Mass Fragmentography
}

\author{
Tateo Suzuki, Kimio Umedzu,* Yasuhiro ItaGaKI** \\ and Katura TUZimurA \\ Laboratory of Analytical Chemistry, Faculty of Agriculture, \\ Tohoku University, Sendai, Japan \\ * Maruwa Biochemicals Co., Kyobashi, Tokyo \\ **Japan Electron Optics Laboratory (JEOL), Akishima, Tokyo \\ Received October 20, 1976
}

\begin{abstract}
Analysis methods of a herbicide "bromacil" were studied comparatively in soil and mandarin orange fruit. Bromacil content in tissue of mouse was also measured. Measurement was performed by gas chromatography with electron capture detector (ECD). Mass fragmentography was also studied, which was found to be useful for the residue analysis of this herbicide.
\end{abstract}

Bromacil (5-bromo-3-sec-butyl-6-methyluracil) is a substituted uracil herbicide which inhibits photosynthesis in sensitive species. ${ }^{11}$ This herbicide is used for long-term, noncrop weed control and utilized efficiently as a selective herbicide in orchard. ${ }^{2}$ In Japan, this herbicide has been used as weed killer in rail way and orange orchard.

The residue analysis of bromacil is practiced using ECD-gas chromatography in ppm-ppb range. But clean-up procedure of the common method is very tedious. ${ }^{3)}$ Recently, Leistra et al. simplified the procedure for soil analysis. ${ }^{4)}$ They extracted bromacil from soil with ethyl acetate and injected the ethyl acetate solution directly to gas chromatograph without further purifications. This method, however, gave troubles in analysis of some kinds of soils. Therefore, the authors studied clean-up procedure including column treatment. On the other hand, an application of mass fragmentography $^{5)}$ on bromacil analysis was studied.

\section{MATERIALS}

Bromacil. Bromacil was extracted with acetone from commercial Hyvar X (containing $80 \%$ of bromacil) and crystallized by addition of water. It was recrystallized from acetone-water and alcohol-water. Melting point was $159^{\circ} \mathrm{C}$ (lit. $158 \sim 159^{\circ} \mathrm{C}$ ). Elementary analysis gave $\mathrm{C} ; 41.47 \%, \mathrm{H} ; 5.08 \%$, and $\mathrm{N}$;
$10.73 \%$ ). Only one peak was obtained on ECD-gas chromatogram by $100 \mathrm{ng}$ injection.

Reagents. Ethyl acetate, acetone and $n$-hexane used were special analytical grade reagents for pesticide residue analysis (Wako Pure Chemicals Co.). Charcoal used was of Mallincrodt Co. Florisil (magnesium silicate, $60 \sim 100$ mesh) was purchased from Floridin Co. Other reagents were commercially available analytical grade reagents.

Soil. Bromacil free soils were obtained from Iwate Agricultural Experiment Station (Morioka) and Frukawa Branch of Miyagi Agricultural Experiment Station (Furukawa). The soil of Morioka was volcanic ash origin and the soil of Furukawa was alluvial origin. These soils had been never-treated with bromacil. Bromacil in acetone solution was mixed with these airdried soils to the concentrations of 1.00 or $0.10 \mathrm{ppm}$ respectively and the acetone was evaporated under the reduced pressure.

Orange. Fruits of mandarin orange "Unshu" were obtained from bromacil-free orchard of Kumamoto Agricultural Experiment Station (Kumamoto). Bromacil was added as acetone solution to the concentration of $0.10 \mathrm{ppm}$ into the homogenized suspension of the peeled fruits.

Mice. Male mice (DD-strain; 10 days of age) were obtained from Mouse Center, School of Medicine, Tohoku University.

\section{METHODS}

\section{Instruments}

Gas chromatograph. Shimadzu GC-3AE gas chro- 
matograph with electron capture detector $\left({ }^{3} \mathrm{H} ; 300 \mathrm{mCi}\right)$ was used under the following conditions.

Column; $1.2 \mathrm{~m} \times 4 \mathrm{~mm}$ glass column, $5 \% \mathrm{XE}-60$ on $60 \sim 80$ mesh Gas Chrom Z.

Temperature of detector, column and injection port; $220^{\circ} \mathrm{C}$ isothermal.

Carrier gas; nitrogen at the pressure of $1.5 \mathrm{~kg} / \mathrm{cm}^{2}$.

Mass fragmentography system. Mass fragmentograms were obtained with JEOL JGC-20KP gas chromatograph-JMS-D-300 mass spectrometer system under the following conditions.

Gas chromatography. column; $1.0 \mathrm{~m} \times 2 \mathrm{~mm}$ glass column, $5 \%$ XE-60 on $60 \sim 80$ mesh Gas Chrom $Z$. Temperature; $220^{\circ} \mathrm{C}$ at column oven, $230^{\circ} \mathrm{C}$ at injection port. Carrier gas; helium at the pressure of $1.0 \mathrm{~kg} /$ $\mathrm{cm}^{2}$.

Mass spectrometry. Accelerating voltage; $3 \mathrm{kV}$. Ionizing voltage; $25 \mathrm{eV}$. Ionizing current; $300 \mu \mathrm{A}$,

Calibration curve. The standard solutions were prepared as acetone solution of bromacil at the range of $0.05 \sim 1.50 \mu \mathrm{g} / \mathrm{ml}$. Five $\mu \mathrm{l}$ of the solution was introduced to the gas chromatograph or mass fragmentography system. Areas of peaks were plotted to their concentrations.

Clean-up procedure. Bromacil contents in orange fruits were analyzed in the similar manner as in the case of soil without further modifications.

Method $1 .^{3)} \quad$ The air-dried soil $(100 \mathrm{~g})$ was mixed with $10 \mathrm{~g}$ of ammonium sulfate, $10 \mathrm{~g}$ of charcoal and $150 \mathrm{ml}$ of $1.5 \%-\mathrm{NaOH}$, and shaken for $5 \mathrm{~min}$. After vacuum filtration, the residue was shaken with $100 \mathrm{ml}$ of water. Filtrates were combined, and the filtrate was shaken with $50 \mathrm{ml}$ of $n$-hexane for $1 \mathrm{~min}$. An aqueous layer was acidified by $5 \mathrm{ml}$ of conc. $\mathrm{HCl}$, followed by shaking with $50 \mathrm{ml}$ of ethyl acetate for 1 min. Ethyl acetate layer was dried over in anhydrous $\mathrm{Na}_{2} \mathrm{SO}_{4}$ and evaporated to dryness under reduced pressure below $50^{\circ} \mathrm{C}$. The residue was dissolved in $5.00 \mathrm{ml}$ of acetone and a $5 \mu \mathrm{l}$ aliquot of the solution was injected to gas chromatograph.

Method 2.4) The soil $35 \mathrm{~g}$ was extracted with $24 \mathrm{ml}$ of ethyl acetate and $25 \mathrm{ml}$ of water under mechanical shaking for $2 \mathrm{hr}$. A $5 \mu \mathrm{l}$ aliquot of the ethyl acetate layer (after centrifugation, if needed) was introduced to gas chromatography.

Method 3. The soil $50 \mathrm{~g}$ was extracted with $50 \mathrm{ml}$ of ethyl acetate and $50 \mathrm{ml}$ of water under mechanical shaking for $2 \mathrm{hr}$. After filtration, the residue was extracted again as before. The ethyl acetate layers were combined and evaporated to dryness under reduced pressure. The residue was dissolved with $2 \mathrm{ml}$ of acetone and mounted on a $1 \times 14 \mathrm{~cm}$ of freshly prepared Florisil column. Elution was performed with acetone at $1 \mathrm{ml} / \mathrm{min}$. After elution of colored materials (approximately $5 \mathrm{ml}$ ), effluents (about $20 \mathrm{ml}$ ) were collected and evaporated to dryness. The residue was dissolved in $5.00 \mathrm{ml}$ of acetone. Five $\mu \mathrm{l}$ of the solution was injected to gas chromatograph.

Bromacil contents in mouse organs. ${ }^{8)}$ Male mice (DD-strain) were maintained on a synthetic diet containing 0,10 and $1000 \mathrm{ppm}$ of bromacil for 4 weeks. Each group consisted of three mice. The bromacil contents of their liver, kidney, spleen and blood were measured.

Each individual organ was weighed and homogenized with $5 \mathrm{ml}$ of saline $(0.85 \%)$ and extracted with $5.00 \mathrm{ml}$ of ethyl acetate. After centrifugation at $5000 \mathrm{rpm}$ for $10 \mathrm{~min}, 5 \mu \mathrm{l}$ of the solvent layer was introduced to gas chromatography.

\section{RESULTS AND DISCUSSION}

\section{Calibration curve}

The data obtained by ECD-gas chromatography and mass fragmentography followed a straight line respectively. Calibration curve using mass fragmentography was shown in Fig. 1 .

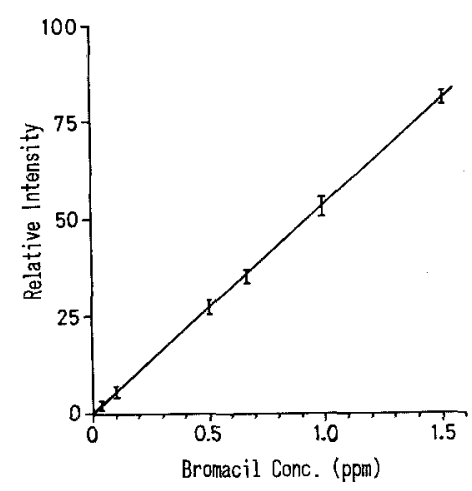

FIG. 1. Calibration Curve for Bromacil Determination.

(Mass Fragmentography)

\section{Bromacil determination in soil}

The analytical results of bromacil fortified soil by ECD-gas chromatography were summerized in Table I. The recovery was varied according to the kinds of soils. On the soil of Morioka, the recovery was satisfactory by every methods. But on the soil of Furukawa, the simplified method (method 2) gave the over-estimated results and the other methods 
Table I. Comparison of ECD-gas Chromatographic Determination of Bromacil Fortified SoILs with Various Clean-up Procedures

Bromacil was added to bromacil free soil to the amount of $1.00 \mathrm{ppm}$ with the air-dried basis.

\begin{tabular}{|c|c|c|c|c|c|}
\hline & & \multicolumn{3}{|c|}{ Found (ppm) } & \multirow{2}{*}{$\frac{\begin{array}{l}\text { Average } \\
\text { recovery }\end{array}}{(\%)}$} \\
\hline & & 1 & 2 & 3 & \\
\hline \multicolumn{6}{|l|}{ Method 1} \\
\hline & Morioka & 0.95 & 0.95 & 0.97 & 95.7 \\
\hline & Furukawa & 0.68 & 0.70 & 0.71 & 69.7 \\
\hline \multicolumn{6}{|l|}{ Method 2} \\
\hline & Morioka & 1.03 & 1.06 & 1.06 & 105.0 \\
\hline & Furukawa & 2.70 & 2.80 & 3.00 & 283.3 \\
\hline \multicolumn{6}{|l|}{ Method 3} \\
\hline & Morioka & 0.96 & 0.97 & 1.01 & 98.0 \\
\hline & Furukawa & 0.72 & 0.73 & 0.76 & 73.7 \\
\hline
\end{tabular}

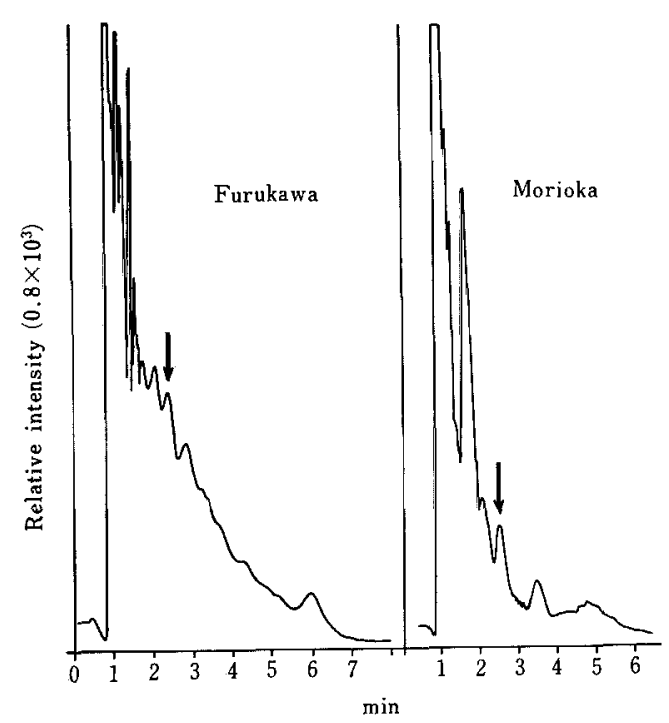

FIG. 2. Gas Chromatograms of Bromacil in Soil (0.10 ppm).

gave the results in low yield. Gas chromatograms of soil were illustrated in Fig. 2, which were obtained by method 2 . Their chromatographic patterns were complicated for exact determination of bromacil content. Especially, pattern of the soil of Furukawa (alluvial) was more complex than those of Morioka (volcanic ash). Therefore, all the method tested had a great limitation to application. For the analysis of bromacil in soil, more improved clean-up procedure must be needed.

\section{Bromacil determination in orange}

The analytical results of mandarin orange were summerized in Table II. The recovery was relatively low, but no significant differences were observed between three methods.

Table II. The Analytical Results of Bromacil Fortified in Orange by ECD-Gas Chromatography

Bromacil was added to the content of $0.10 \mathrm{ppm}$.

\begin{tabular}{lcccc}
\hline & & Found (ppm) & & $\begin{array}{r}\text { Average } \\
\text { recovery }\end{array}$ \\
\hline & 1 & 2 & 3 & $(\%)$ \\
Method 1 & 0.083 & 0.085 & 0.087 & 85.0 \\
Method 2 & 0.090 & 0.090 & 0.090 & 90.0 \\
Method 3 & 0.086 & 0.086 & 0.086 & 86.0 \\
\hline
\end{tabular}

\section{Mass fragmentography}

Mass spectrum of bromacil was illustrated in Fig. 3. ${ }^{6)}$ Peak at 205 mass, which was derived from $\mathrm{M}$-(sec-butyl group), was very dominant as large as the peak at 207 mass. Therefore, mass fragmentograms were obtained at 205 mass. Mass fragmentogram of soil of Furukawa was illustrated in Fig. 4. Sample solution of this fragmentogram was ethyl acetate extract of soil prepared according to the simplified method (method 2). The mass fragmentogram was very simple and the determination of bromacil was easy. The results of recovery test by mass fragmentography were shown in Table III. Thus, mass fragmentography seems to be promising to the residue analysis in soil and perhaps to other agricultural products. Detection limit with mass fragmentography using electron impact 


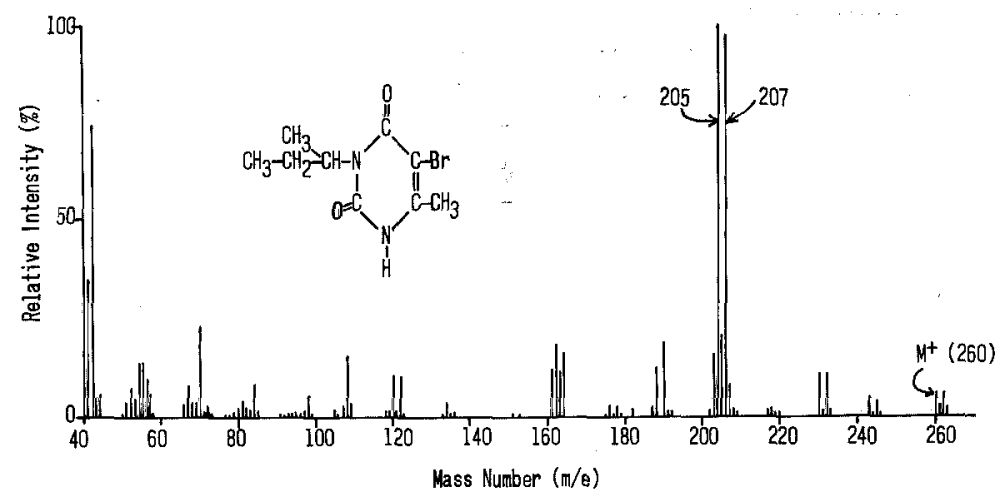

FIG. 3. Mass Spectrum of Bromacil $(25 \mathrm{eV}, 300 \mu \mathrm{A})$.

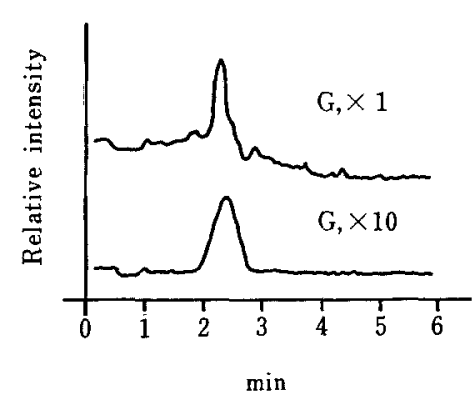

FIG. 4. Mass Fragmentogram of Bromacil in Soil of Furukawa. (0.10 ppm; under line, $1.00 \mathrm{ppb}$; upper line)

Mass Fragmentograms were obtained at 205 mass. $\mathrm{G}$ is the sensitivity indication of the galvanometer of the instrument.
Table III. Recovery Test of Bromacil ForTIFIED IN SOIL by MASS

FRAGMENTOGRAPHY (RECOVERY, \%)

Bromacil was added to soils to the concentration of 1.00 ppm.

\begin{tabular}{ccc}
\hline & Morioka & Furukawa \\
\hline Method 1 & 98.0 & 97.3 \\
Method 2 & 98.5 & 99.0 \\
Method 3 & 90.2 & 92.7 \\
\hline
\end{tabular}

summerized in Table IV. The procedure was slightly modified from the simplified method. These gas chromatograms were simple compared with those of soil and orange, so that the determination should be reliable.

Table IV. Bromacil Contents in Some Organs of the Feeded Mouse ppm in wet basis.

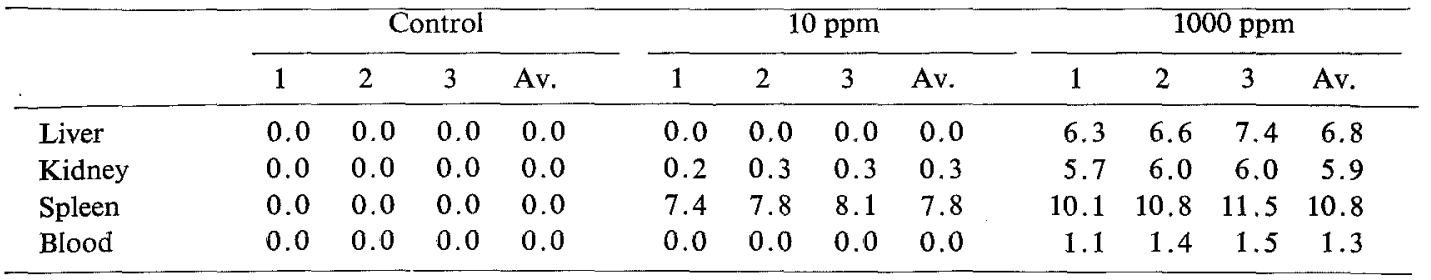

ion sourse is $1 \mathrm{ng} / \mathrm{ml}$ ( $1 \mathrm{ppb}$ ). If chemical ionization is used as ionization part, detection limit is expected to be more improved, since the fragmentation of bromacil shall be minimized.

\section{Bromacil content in mice organs}

The analytical results of organs of mice were
Acknowledgement. Authors thank to Mr. Shin'ichi Nanbu and Mr. Kyosuke Morimoto for their technical assistances.

\section{REFERENCES}

1) C. E. Hoffman, J. W, McGahan and P. B. Sweetser, Nature, 202, 577 (1964).

2) B. E. Day, L. S. Jordan, J. D. Mann and R. C. 
Russell, Calif. Citrograph, 49, 371 (1964).

3) V. A. Jolliffe, B. E. Day, L. S. Jordan and J. D. Mann, J. Agr. Food Chem., 15, 174 (1967).

4) M. Leistra, J. H. Smelt and R. Zandvoort, Weed Res., 15, 243 (1975).
5) B. A. Karlhuber, W. D. Hörmann and K. A. Ramsteiner, Anal. Chem., 47, 2450 (1975).

6) J. A. Gardiner, R. W. Reiser and H. Sherman, J. Agr. Food Chem., 17, 967 (1969). 